\title{
ANALISIS PERTUMBUHAN SIMPANAN PADA PT. BPR GISAWA CABANG NEGARA PERIODE TAHUN 2013-2016
}

\author{
Pande Made Ayu Noveantari Santi Dewi \\ Jurusan Pendidikan Ekonomi \\ Universitas Pendidikan Ganesha \\ Singaraja, Indonesia
}

Email: madepande75@yahoo.co.id

\begin{abstract}
Abstrak
Penelitian ini bertujuan untuk mengetahui tingkat pertumbuhan jumlah simpanan dan penyebab terjadinya fluktuasi tingkat pertumbuhan simpanan tabungan dan deposito pada PT. BPR Gisawa Cabang Negara periode tahun 2013-2016. Jenis penelitian ini adalah deskriptif kuantitatif. Data dikumpulkan dengan metode dokumentasi. Analisis data menggunakan teknik analisis trend yang dibantu dengan menggunakan software SPSS. Hasil penelitian menunjukkan bahwa tingkat pertumbuhan jumlah simpanan tabungan dan deposito pada PT. BPR Gisawa Cabang Negara periode tahun 2013-2016 mengalami fluktuasi setiap tahunnya. Tingkat pertumbuhan jumlah simpanan tabungan tahun 2013 Rp. 7.819.456.299, tahun 2014 menurun 3.56\% menjadi Rp. 8.253.811.109, tahun 2015 menurun 29.46\% menjadi Rp. 6.223.044.567, tahun 2016 menurun 6.01\% menjadi Rp. 5.364.001.736. Tingkat pertumbuhan jumlah simpanan deposito tahun $2013 \mathrm{Rp} .4 .435 .500 .000$, tahun 2014 menurun $18.38 \%$ menjadi Rp. 2.936.000.000, tahun 2015 menurun 5.63\% menjadi Rp. 2.239.300.000, tahun 2016 meningkat $2.56 \%$ menjadi Rp. 2.196.500.000, penyebab terdinya fluktuasi tingkat pertumbuhan simpanan tabungan dan deposito pada PT. BPR Gisawa Cabang Negara periode tahun 2013-2016 karena beberapa faktor yaitu tingkat kepercayaan nasabah yang masih cenderung rendah terhadap PT. BPR Gisawa, dan tingkat persaingan antar Bank Perkreditan Rakyat yang tinggi dapat mengakibatkan bergesernya kepercayaan nasabah untuk melakukan transaksi di PT. BPR Gisawa
\end{abstract}

Kata kunci: tingkat pertumbuhan, tabungan, deposito.

\begin{abstract}
Abstact
This study aimed to determine the growth rate of savings and deposits at PT. BPR Gisawa Branch Negara for the period of 2013-2016, the cause of the fluctuation of the growth rate of savings and deposits deposits at PT. BPR Gisawa Branch Negara for the period of 2013-2016. Data were collected by documentation method. Data analysis using trend analysis technique assisted by using SPSS software. The results of this study showed that growth rate of savings and deposits at PT. BPR Gisawa Branch Negara for the period of 2013-2016 fluctuates annually. The growth rate of total savings in 2013 Rp. 7,819,456,299, the year 2014 decreased $3.56 \%$ to Rp. 8,253,811,109, the year 2015 decreased $29.46 \%$ to Rp. $6,223,044,567$, the year 2016 decreased $6.01 \%$ to Rp. 5.364.001.736. The growth rate of deposit savings in 2013 Rp. 4,435,500,000, the year 2014 decreased $18.38 \%$ to Rp. 2.936 million, the year 2015 decreased $5.63 \%$ to Rp. 2.239.300.000, the year 2016 increased $2.56 \%$ to Rp. 2.196.500.000, the cause of fluctuations in the growth rate of savings deposits and deposits at PT. BPR Gisawa Branch Negara for the period of 2013-2016 because to several factors namely the level of customer confidence that still tend to be low against PT. BPR Gisawa, and high level of competition between Rural Banks may result in shifting customers' trust to conduct transactions at PT. BPR Gisawa
\end{abstract}

Keywords: growth rate, savings, deposits. 


\section{PENDAHULUAN}

Lembaga keuangan merupakan perusahaan yang bergerak dibidang keuangan, menghimpun dana, menyalurkan dana atau kedua-duanya. Berdasarkan UU Perbankan Nomor 14 Tahun 1967 pasal 1 ayat $b$ mendefinisikan bahwa yang dimaksud dengan lembaga keuangan adalah semua badan yang melakukan kegiatan-kegiatan dibidang keuangan yaitu menghimpun dana dan menyalurkannya ke masyarakat. Kegiatan utama dalam lembaga keuangan yaitu membiayai permodalan suatu bidang usaha disamping usaha lain seperti menampung uang yang sementara waktu belum digunakan oleh pemiliknya. Lembaga keuangan di Indonesia dibedakan menjadi dua, yaitu lembaga keuangan bukan bank dan lembaga keuangan bank.

Lembaga Keuangan Bukan Bank (LKBB) merupakan badan usaha yang melakukan kegiatan dalam bidang keuangan yang secara langsung dan tidak langsung menghimpun dana dan menyalurkan ke masyarakat yang berguna membiayai investasi perusahaan. Lembaga Keuangan Bukan Bank (LKBB) terdiri dari lembaga keuangan kontraktual, lembaga keuangan investasi, dan lembaga keuangan pembiayaan. Adapun jenis-jenis Lembaga Keuangan Bukan Bank yaitu, pasar modal, pasar uang, koperasi simpan pinjam, perusahaan pegadaian, perusahaan leasing, perusahaan kartu plastik, dana pensiun, perusahaan modal ventura, perusahaan anjak piutang, dan perusahaan asuransi.

Lembaga Keuangan Bank (LKB) merupakan lembaga yang memberikan jasa-jasa keuangan dan menarik dana dari masyarakat secara langsung. Lembaga keuangan bank sering disebut dengan depository intermediary. Lembaga Keuangan Bank menghimpun dana secara langsung dari masyarakat dalam bentuk simpanan seperti giro, tabungan atau deposito berjangka yang diterima oleh penabung atau unit surplus.

Menurut Kasmir (2015:12), bank adalah lembaga keuangan yang kegiatan utamanya adalah menghimpun dana dari masyarakat dan menyalurkan kembali dana tersebut ke masyarakat serta memberikan jasa bank lainnya. Menurut Hasibuan (2005:2), bank adalah lembaga usaha yang kekayaannya terutama dalam bentuk asset keuangan serta bermotif profit juga sosial, jadi bukan hanya mencari keuntungan saja. Menurut Ikatan Akuntan Indonesia (2002:31), bank adalah lembaga yang berperan sebagai perantara keuangan antara pihak yang memiliki dana dan pihak yang memerlukan dana, serta lembaga yang berfungsi memperlancar lalu lintas pembayaran. Menurut Parera (2004:137), bank adalah badan usaha yang menghimpun dana dari masyarakat dalam bentuk simpanan dan menyalurkan dana tersebut kembali kepada masyarakat dalam bentuk kredit atau bentuk-bentuk lainnya dalam rangka meningkatkan taraf hidup rakyat banyak.

Menurut Undang-Undang RI Nomor 10 Tahun 1998 tanggal 10 November 1998 tentang perbankan, bank adalah badan usaha yang menghimpun dana dari masyarakat dalam benuk simpanan dan menyalurkannya kepada masyarakat dalam bentuk kredit dan/bentuk-bentuk lainnya dalam rangka meningkatkan taraf hidup rakyat banyak. Menurut Susilo dkk (2000:6), secara umum fungsi utama bank adalah menghimpun dana dari masyarakat dan menyalurkan kembali kepada masyarakat untuk berbagai tujuan atau sebagai financial intermediary. Menurut Undang-Undang Nomor 7 Tahun 1992 dan ditegaskan lagi dengan keluarnya UndangUndang RI Nomor 10 Tahun 1998, maka jenis perbankan terdiri dari dua jenis bank, yaitu, bank umum, Bank Perkreditan Rakyat (BPR).

Bank Umum adalah usaha yang meliputi tiga kegiatan utama, yaitu menghimpun dana, menyalurkan dana, memberikan jasa bank lainnya. Sebuah bank umum konvensional, saat pertama didirikan harus memiliki modal sedikitnya Rp 3.000.000.000.000, bank umum melayani semua aktivitas BPR ditambah layanan lain seperti menerbitkan surat atas pengkuan hutang, membuat surat pengakuan hutang, menyediakan tempat penyimpanan surat berharga dan barang, 
kegiatan valuta asing dan kegiatan bank umum pada umumnya. Bank umum juga melayani transaksi keuangan mulai dari kliring, inkaso, valuta asing dan transfer yang tidak bisa dilayani BPR. Bank umum melayani kredit dan simpanan yang lebih lengkap dan kompleks yang secara umum meliputi layanan BPR ditambah beberapa produk seperti kredit konsumtif, kredit tanpa agunan (KTA), kartu kredit, kredit property, kredit kendaraan bermotor, kredit investasi dan kredit modal kerja berbagai segmen nasabah, simpanan nasabah juga dijamin LPS dengan bunga di kisaran 6,25\% untuk deposito rupiah dan $0,25 \%$ untuk depsito valas. Secara umum bunga simpanan di BPR relative lebih tinggi dibandingkan bank umum namun dengan konsekuensi bunga kreditnya juga lebih tinggi dibandingkan bunga kredit bank umum. Bank umum memiliki jangkauan luas yang tak terbatas, hingga memiliki jaringan internasional. Hal ini sekaligus berpengaruh pada kondisi fisik kantor, dimana BPR biasanya tak semegah bank umum. Masyarakat pasti juga sudah tidak asing dengan bank umum, beda halnya dengan BPR yang hanya diketahui oleh masyarakat sekitar lokasi kantor tersebut.

Menurut Kasmir (2002:21), bank perkreditan rakyat adalah bank yang melaksanakan kegiatan usaha secara konvensional atau berdasarkan prinsip syariah yang dalam kegiatannya tidak memberikan jasa dalam lalu lintas pembayaran (UU No. 10 Tahun 1998 tentang perbankan). Bank perkreditan rakyat adalah bank yang kegiatannya menerima simpanan hanya dalam bentuk deposito berjangka, tabungan dan atau bentuk lainnya yang dapat dipersamakan dengan itu. Larangan bagi BPR adalah menerima rekening giro serta melaksanakan kiring. Begitu pula dengan jangkauan wilayah oprasinya sangat terbatas di kecamatan-kecamatan dan pedesaan saja. Selanjutnya pendirian BPR dengan modal awal yang relative lebih kecil yaitu Rp 1.000.000.000.000 jika dibandingkan dengan modal awal Bank Umum.

Pada awalnya tugas pokok BPR diarahkan untuk menunjang pertumbuhan dan modernisasi ekonomi pedesaan serta mengurangi praktk-praktek iin para pelepas uang. Seiring dengan perkembangan kebutuhan masyarakat, pada akhirnya tugas BPR tidak hanya ditunjukkan bagi masyarakat golongan ekonomi lemah di daerah perkotaan. Sasaran BPR adalah golongan masyarakat yang belum dijangkau oleh Bank Umum seperti petani, peternak, nelayan, pedagang, pengusaha kecil, pegawai, dan pensiunan sehingga keberadaan BPR akan mewujudkan pemerataan layanan perbankan, pemerataan kesempatan berusaha, pemeratan pendapatan, dan agar mereka tidak jatuh ke tangan para Perbankan No. 10 tahun 1998 pasal 13 dan pasal 1 terdapat usaha yang dilakukan oleh Bank Perkreditan Rakyat.

Menurut Ismail (2011:15), Bank Perkreditan Rakyat adalah bank yang melaksanakan kegiatan usaha secara konvensional atau berdasarkan prinsip syariah yang dalam kegiatannya tidak memberikan jasa dalam lalu lintas pembayaran atau giral. Berdasarkan UU Perbankan Nomor 10 Tahun 1998 tanggal 10 November 1998 mendefinisikan Bank Perkreditan Rakyat adalah bank yang kegiatannya menerima simpanan hanya dalam bentuk deposito berjangka, tabungan dan atau bentuk lainnya yang dapat dipersamakan dengan itu.

Bank Perkreditan Rakyat (BPR) mempunyai peranan yang sangat strategis karena selama ini telah melayani usaha mikro kecil dan warga masyarakat melalui jasa keuangan yang dilakukan sesuai dengan kebutuhan nasabah yaitu, prosedur yang sederhana, proses yang singkat, pendekatan personal serta kedekatan lokasi BPR. Dengan menawarkan jenis produk-produk BPR, diharapkan nasabah akan tertarik sehingga kembali melakukan transaksi berulang-ulang pada BPR ini.

PT. BPR Gisawa mengalami fluktuasi pertumbuhan simpanan tabungan dan deposito pada periode tahun 20132016 dengan rincian sebagai berikut. Pada tahun 2013 pertumbuhan jumlah simpanan tabungan di BPR gisawa sebesar Rp 7.819.456.299. Pada tahun 2014 pertumbuhan jumlah simpanan tabungan di 
BPR Gisawa mengalami fluktuasi kenaikan menjadi $\mathrm{Rp}$ 8.253.811.109. Pada tahun 2015 pertumbuhan jumlah simpanan tabungan di BPR Gisawa mengalami fluktuasi penurunan menjadi $\mathrm{Rp}$ 6.223.044.567. Dan pada tahun 2016 pertumbuhan jumlah simpanan tabungan di BPR gisawa mengalami fluktuasi penurunan menjadi Rp 5.364.001.736.

Pada tahun 2013 pertumbuhan jumlah simpanan deposito di BPR gisawa sebesar $\mathrm{Rp}$ 4.435.500.000. Pada tahun 2014 pertumbuhan jumlah simpanan deposito di BPR Gisawa mengalami fluktuasi penurunan menjadi $R p$ 2.936.000.000. Pada tahun 2015 pertumbuhan jumlah simpanan deposito di BPR Gisawa mengalami fluktuasi penurunan menjadi Rp 2.239.300.00. Dan pada tahun 2016 pertumbuhan jumlah simpanan deposito di BPR gisawa mengalami fluktuasi penurunan menjadi $\mathrm{Rp}$ 2.196.500.000.

Dalam pertumbuhan jumlah simpanan tabungan dan deposito pada PT. BPR Gisawa Cabang Negara periode tahun 2013-2016 mengalami fluktuasi yang disebabkan oleh beberapa faktor di dalam keputusan yang diambil oleh nasabah. Menurut Kotler (2005:203), Faktor-faktor yang mempengaruhi keputusan nasabah adalah faktor budaya, sosial, pribadi, dan psikologis. Tingkat persaingan yang tinggi dapat mengakibatkan bergesernya loyalitas nasabah pada PT. BPR Gisawa Cabang Negara dengan BPR lainnya seperti, BPR Nusamba Kubutambahan Cabang Negara, BPR Adi Sedana Ayu, BPR Suryajaya Ubud Cabang Negara, dan BPR Dharmawarga Utama. Kondisi seperti ini mendorong pihak bank untuk senantiasa melakukan riset pasar kepada konsumen sehingga dapat diketahui keinginan dan kebutuhan konsumen terhadap PT. BPR Gisawa Cabang Negara. Melihat dari permasalahan tersebut, maka perlu dilakukan penelitian dengan judul Analisis Pertumbuhan Simpanan Pada Pt. Bpr Gisawa Cabang Negara Periode Tahun 2013-2016.

$$
\text { Menurut Kasmir (2003:65), }
$$

"simpanan adalah dana yang dipercayakan masyarakat untuk dititipkan di bank, dana tersebut kemudian dikelola oleh bank dalam bentuk simpanan, seperti rekening giro, rekening tabungan, dan rekening deposito untuk kemudian diusahakan kembali dengan cara disalurkan ke masyarakat". Berdasarkan Undang-Undang Perbankan Nomor. 10 tahun 1998 pasal 1 butir (5), tentang perubahan atas Undang-Undang Perbankan No. 7 tahun 1992, menyatakan bahwa simpanan adalah dana yang dipercayakan masyarakat kepada bank berdasarkan perjanjian penyimpanan dana dalam bentuk giro, deposito, tabungan dan atau bentuk-bentuk lainnya yang dipersamakan dengan itu.

Menurut Kotler (2002), simpanan dapat dikatakan sebagai sumber daya yang dapat dipergunakan bank dalam bentuk simpanan yang umumnya disebut giro, deposito berjangka, dan tabungan. Berdasarkan Undang-Undang Perbankan No. 10 tahun 1998 pasal 13 dan pasal 1, Bank Perkreditan Rakyat dilarang untuk menerima simpanan berupa giro dan ikut serta dalam lalu lintas pembayaran. Jadi Bank Perkreditan Rakyat hanya diperbolehkan melakukan kegiatan menghimpun dana dari masyarakat dalam bentuk simpanan berupa deposito berjangka dan tabungan.

Menurut UU Perbankan No.10 Tahun 1998 tabungan adalah simpanan yang pada penarikannya hanya dapat dilakukan menurut syarat tertentu yang telah disepakati, namun tidak dapat ditarik dengan cek, bilyet giro atau alat lainnya yang dipersamakan dengan itu. Menurut Kasmir (2002:84), tabungan adalah penarikannya hanya dapat dilakukan menurut syarat-syarat tertentu. Menurut Simurangkir (2004:11), tabungan adalah simpanan dana pihak ketiga kepada bank yang penarikannya hanya dapat dilakukan menurut syarat-syarat yang ditentukan antara bank dan nasabah. Menurut Susilo (2004:64), tabungan adalah simpanan yang penarikannya hanya dapat diilakukan dengan syarat tertentu yang lebih disepakati, dan tidak menggunakan cek atau bilyet giro atau alat lainnya dapat dipersamakan oleh hal itu. Cara penarikan rekening tabungan ini biasanya menggunakan cashcard atau ATM, dan debt card.

Pande Made Ayu I Page 16 dari 51 
Menurut statistik ekonomi keuangan Indonesia (2011), tabungan adalah simpanan pada bank dalam rupiah milik pihak ketiga, yang penarikan hanya dapat dilakukan menurut syarat-syarat tertentu yang disepakati tetapi tidak dapat ditarik dengan cek atau alat yang dapat dipersamakan dengan itu.

Menurut Sinungan (2003:3), tabungan adalah simpanan pihak ketiga pada bank yang penerikannya hanya dapat dilakukan menurut syarat-syarat tertentu. Menurut Veithzal (2007:415), Tabungan adalah simpanan yang penerikannya harus dapat di lakukan dengan syarat tertentu yang disepakati, dan tidak dengan cek, bilyet giro atau alat lain yang dipersamakan dengan itu. Menurut Sinungan (2000:25), Faktor yang mempengaruhi tabungan, yang merupakan hal penting dan sebagai upaya memenuhi segala kebutuhan nasabah dengan fasilitas yang tersedia seperti. Tingkat bunga, merupakan hal penting bagi suatu bank dalam penarikan tabungan dan penyaluran kreditnya. Penarikan tabungan dan pemberian kredit selalu berhubungan dengan tingkat suku bunganya. Bunga bagi bank bias menjadi biaya (cost of fund) yang harus dibayarkan pada penabung, tetapi dilain pihak, bunga dapat juga merupakan pendapatan bank yang diterima dari debitor karena kredit yang diberikan, Masyarakat (nasabah) pada hakekatnya mengharapkan sesuatu yang lebih dari pada sekedar mandapatkan jasa berupa bunga dari bank. Nasabah juga ingin mendapatkan hadiahhadiah yang ditawarkan oleh bank dengan syarat-syarat selain memanfatkan jasa bank, Pelayanan diartikan sebagai upaya pihak bank untuk memenuhi segala kebutuhan nasabah dengan fasilitas yang tersedia. Pelayanan yang baik, ramah, dan sopan serta memberikan fasilitas-fasilitas yang tersedia secara optimalkan membuat nasabah puas, Terjadinya peredaran perdagangan yang cepat dan perindustrian yang semakin berkembang memberikan kemungkinan kepada perusahaan atau perorangan yang keuangannya berlebih dalam pendapatannya. Dengan demikian ia akan menitipkan uangnya tersebut kepada bank.
Menurut Kasmir (2003:80), deposito adalah simpanan yang dapat dilakukan pada waktu tertentu berdasarkan perjanjian nasabah penyimpan dengan bank.

Menurut Simurangkir (2002), deposito adalah uang yang disetor oleh seseorang sebagai uang panjar atau uang muka, baik telah dikredit macet maupun akan dikredit kepadanya atas nama deposito atau uang muka, baik jumlah tersebut akan telah dibayar kepada kreditur atau pemilik atau seseorang lainnya, atau akan telah dilunaskan melalui pembayaran uang atau transfer atau melalui penyerahan barangbarang atau dengan cara lain.

Berdasarkan Undang-undang No. 10 Tahun 1998 Pasal 1 ayat 7 deposito adalah simpanan yang penarikannya hanya dapat dilakukan pada waktu tertentu sesuai dengan perjanjian antara pihak nasabah dengan bank. Menurut Kasmir (2012), deposito adalah simpanan jenis ketiga yang dikeluarkan oleh bank. Menurut Nazir dan Hassanudin (2004), deposito atau simpanan berjangka merupakan simpanan pihak ketiga pada bank yang hanya bisa dilakukan penarikan sesuai dengan jangka waktu yang telah ditentukan menurut perjanjian oleh pihak ketiga dan pihak bank. Menurut Suyatno (2004), deposito adalah simpanan bank yang penarikannya hanya dapat dilakukan dalam waktu tertentu sesuai dengan perjanjian nasabah dengan bank yang bersangkutan.

Jenis penelitian ini adalah penelitian deskriptif kuantitatif. Fokus pengamatan dalam penelitian ini adalah tingkat pertumbuhan simpanan pada PT. BPR Gisawa Cabang Negara periode tahun 2013-2016. Dalam penelitian ini, peneliti melakukan observasi mendalam dengan pihak Pimpinan Cabang dan staf pegawai funding officer untuk mendapatkan data tentang jumlah pertumbuhan saldo simpanan tabungan dan deposito. Penelitian ini bermaksud untuk memberikan informasi tentang pertumbuhan simpanan, dan upaya untuk mengoptimalkan jumlah penerimaan simpanan pada PT BPR Gisawa Cabang Negara.

\section{METODE}


Penelitian ini menggunakan data kuantitatif. Data kuantitatif dalam penelitian ini berupa saldo atau jumlah simpanan yang diperoleh dari nasabah yang melakukan transaksi di PT BPR Gisawa Cabang Negara.

Data yang digunakan dalam penelitian ini berupa data sekunder. Data sekunder adalah sumber data penelitian yang diperoleh melalui media perantara atau secara tidak langsung yang berupa buku, catatan, ataupun arsip. Data sekunder dalam penelitian ini berupa jumlah simpanan PT BPR Gisawa Cabang Negara.

Metode pengumpulan data yang digunakan dalam penelitian ini adalah metode dokumentasi dan wawancara dipergunakan dalam penelitian ini untuk mendapat kan data pertumbuhan jumlah simpanan di PT BPR Gisawa cabang Negara periode tahun 2013-2016.

Teknik analisis data yang digunakan dalam penelitian ini adalah analisis trend yang dibantu dengan menggunakan software SPSS. Software SPSS bisa memudahkan dalam meramalkan kejadian masa depan berdasarkan data masa lalu. Data masa lalu akan membentuk suatu rangkaian waktu data (time series). Analisis rangkaian waktu adalah untuk meramalkan atau memprediksi nilai masa depan (Trihendradi, 2013:281). Data masa lalu dalam penelitian ini yaitu data jumlah simpanan pada tiga tahun terakhir yaitu dari tahun 2013 sampai tahun 2016. Data dari tiga tahun tersebut dapat meramalkan jumlah simpanan pada tahun yang akan datang melalui software SPSS.

\section{HASIL DAN PEMBAHASAN Hasil}

Tingkat Pertumbuhan Jumlah Simpanan Tabungan pada PT. BPR Gisawa Cabang Negara Periode Tahun 2013-2016. PT. BPR Gisawa Cabang Negara mengalami fluktuasi pertumbuhan simpanan tabungan selama tiga tahun terakhir yaitu periode tahun 2013-2016. Tingkat pertumbuhan jumlah simpanan tabungan pada PT. BPR Gisawa Cabang Negara dapat dilihat pada tabel 1 sebagai berikut.

Berdasarkan tabel 1 pada tahun 2013 dapat dijelaskan jumlah saldo tabungan berfluktuasi setiap bulannya. Pada bulan Januari jumlah saldo tabungan sebesar Rp. 8.262.446.000. Pada bulan Februari menurun sebesar $5.33 \%$, pada bulan Maret menurun sebesar $4.57 \%$, pada bulan April meningkat sebesar $2.11 \%$, pada bulan Mei meningkat sebesar $13.26 \%$, pada bulan Juni menurun sebesar $11.18 \%$, pada bulan Juli meningkat sebesar $1.58 \%$, pada bulan Agustus meningkat sebesar 3.71\%, pada bulan September menurun sebesar $6.87 \%$, pada bulan Oktober meningkat sebesar $19.04 \%$, pada bulan November menurun sebesar $9.10 \%$, pada bulan Desember menurun sebesar $3.94 \%$. Pada bulan Maret merupakan jumlah saldo tabungan terendah yaitu sebesar $\mathrm{Rp}$. 7.465.102.000. Sedangkan pada bulan Oktober merupakan jumlah saldo tabungan tertinggi yaitu Rp. 8.955.358.000.

Berdasarkan tabel 1 pada tahun 2014 dapat dijelaskan jumlah saldo tabungan berfluktuasi setiap bulannya. Pada bulan Januari jumlah saldo tabungan sebesar Rp. 7.498.155.000. Pada bulan Februari menurun sebesar $11.59 \%$, pada bulan Maret meningkat sebesar $3.02 \%$, pada bulan April meningkat sebesar $11.17 \%$ , pada bulan Mei meningkat sebesar $2.69 \%$, pada bulan Juni menurun sebesar $0.32 \%$, pada bulan Juli menurun sebesar $5.71 \%$, pada bulan Agustus meningkat sebesar 8.36\%, pada bulan September meningtkat sebesar $2.78 \%$, pada bulan Oktober meningkat sebesar $1.57 \%$, pada bulan November menurun sebesar $0.05 \%$, pada bulan Desember menurun sebesar $0.36 \%$. Pada bulan Februari merupakan jumlah saldo tabungan terendah yaitu sebesar $\mathrm{Rp}$. 6.628.938.000. Sedangkan pada bulan November merupakan jumlah saldo tabungan tertinggi yaitu Rp. 8.283.218.000.

Berdasarkan tabel 1 tahun 2015 dapat dijelaskan jumlah saldo tabungan berfluktuasi setiap bulannya. Pada bulan Januari jumlah saldo tabungan sebesar Rp. 4.822.271.000. Pada bulan Februari menurun sebesar $2.10 \%$, pada bulan Maret meningkat sebesar $8.13 \%$, pada bulan April menurun sebesar $5.02 \%$, pada bulan Mei meningkat sebesar $37.39 \%$, pada bulan Juni menurun sebesar $19.19 \%$, pada bulan Juli menurun sebesar $7.62 \%$, pada bulan

Pande Made Ayu I Page 18 dari 51 
Agustus meningkat sebesar $7.36 \%$, pada bulan September meningtkat sebesar $5.51 \%$, pada bulan Oktober menurun sebesar $0.03 \%$, pada bulan November meningkat sebesar $3.31 \%$, pada bulan Desember meningkat sebesar $6.97 \%$. Pada bulan Februari merupakan jumlah saldo tabungan terendah yaitu sebesar Rp. 4.720.963.000. Sedangkan pada bulan Mei merupakan jumlah saldo tabungan tertinggi yaitu Rp. 6.661.490.000.

Berdasarkan tabel 1 tahun 2016 dapat dijelaskan jumlah saldo tabungan berfluktuasi setiap bulannya. Pada bulan Januari jumlah saldo tabungan sebesar Rp. 4.228.396.000. Pada bulan Februari menurun sebesar $10.37 \%$, pada bulan Maret meningkat sebesar $12.87 \%$, pada bulan April meningkat sebesar $36.36 \%$, pada bulan Mei menurun sebesar $10.70 \%$, pada bulan Juni meningkat sebesar $17.96 \%$, pada bulan Juli meningkat sebesar $8.46 \%$, pada bulan Agustus menurun sebesar $12.38 \%$, pada bulan September menurun sebesar $31.70 \%$, pada bulan Oktober meningkat sebesar $16.26 \%$, pada bulan November meningkat sebesar $13.71 \%$, pada bulan Desember meningkat sebesar $1.76 \%$. Pada bulan Februari merupakan jumlah saldo tabungan terendah yaitu sebesar Rp. 3.789.855.000. Sedangkan pada bulan Juli merupakan jumlah saldo tabungan tertinggi yaitu $\mathrm{Rp}$. 6.663.728.000.

Tabel 1 Pertumbuhan Jumlah Simpanan Tabungan Periode Tahun 2013-2016.

\begin{tabular}{|c|c|c|c|c|c|c|c|c|}
\hline Bulan & $\begin{array}{l}2013 \\
\text { (Dalam } \\
\text { ribuan) } \\
(\mathrm{Rp})\end{array}$ & $\%$ & $\begin{array}{c}2014 \\
\text { (Dalam } \\
\text { ribuan) } \\
\text { (Rp) }\end{array}$ & $\%$ & $\begin{array}{c}2015 \\
\text { (Dalam } \\
\text { ribuan) } \\
\text { (Rp) }\end{array}$ & $\%$ & $\begin{array}{l}2016 \\
\text { (Dalam } \\
\text { ribuan) } \\
(\mathrm{Rp})\end{array}$ & $\%$ \\
\hline Januari & 8.262 .446 & & 7.498 .155 & $-4.11 \%$ & 4.822.271 & $-41.58 \%$ & 4.228.396 & $-32.05 \%$ \\
\hline Februari & 7.822 .386 & $-5.33 \%$ & 6.628 .938 & $-11.59 \%$ & 4.720 .963 & $-2.10 \%$ & 3.789 .855 & $-10.37 \%$ \\
\hline Maret & 7.465 .102 & $-4.57 \%$ & 6.829 .008 & $3.02 \%$ & 5.104 .780 & $8.13 \%$ & 4.277 .729 & $12.87 \%$ \\
\hline April & 7.622 .841 & $2.11 \%$ & 7.592.099 & $11.17 \%$ & 4.848 .599 & $-5.02 \%$ & 5.832 .900 & $36.36 \%$ \\
\hline Mei & 8.633.289 & $13.26 \%$ & 7.795.976 & $2.69 \%$ & 6.661 .490 & $37.39 \%$ & 5.208 .644 & $-10.70 \%$ \\
\hline Juni & 7.668 .183 & $-11.18 \%$ & 7.770 .664 & $-0.32 \%$ & 5.383 .043 & $-9.19 \%$ & 6.144 .038 & $17.96 \%$ \\
\hline July & 7.789 .080 & $1.58 \%$ & 7.326 .668 & $-5.71 \%$ & 4.972 .825 & $-7.62 \%$ & 6.663 .728 & $8.46 \%$ \\
\hline Agustus & 8.078 .054 & $3.71 \%$ & 7.939.301 & $8.36 \%$ & 5.338 .665 & $7.36 \%$ & 5.838 .466 & $-12.38 \%$ \\
\hline September & 7.523 .081 & $6.87 \%$ & 8.159 .806 & $2.78 \%$ & 5.632 .624 & $5.51 \%$ & 3.987 .598 & $-31.70 \%$ \\
\hline Oktober & 8.955.358 & $19.04 \%$ & 8.287 .543 & $1.57 \%$ & 5.630 .800 & $-0.03 \%$ & 4.635 .856 & $16.26 \%$ \\
\hline November & 8.140 .418 & $-19.10 \%$ & 8.283 .218 & $-0.05 \%$ & 5.817 .322 & $3.31 \%$ & 5.271 .393 & $13.71 \%$ \\
\hline Desember & 7.819 .456 & $-3.94 \%$ & 8.253 .811 & $-0.36 \%$ & 6.223 .044 & $6.97 \%$ & 5.364 .001 & $1.76 \%$ \\
\hline
\end{tabular}

Sumber: PT.BPR Gisawa Cabang Negara.

Tingkat Pertumbuhan Jumlah Simpanan Deposito Pada PT. BPR Gisawa Cabang Negara Periode Tahun 2013-2016. PT. BPR Gisawa Cabang Negara mengalami fluktuasi pertumbuhan simpanan deposito selama tiga tahun terakhir yaitu periode tahun 2013-2016. Tingkat pertumbuhan jumlah simpanan tabungan 
pada PT. BPR Gisawa Cabang Negara dapat dilihat pada tabel 2 sebagai berikut.

Berdasarkan tabel 2 tahun 2013 dapat dijelaskan jumlah saldo deposito berfluktuasi setiap bulannya. Pada bulan Januari jumlah saldo deposito sebesar Rp. 2.906.000.000. Pada bulan Februari meningkat sebesar $2.08 \%$, pada bulan Maret menurun sebesar $3.61 \%$, pada bulan April menurun sebesar $3.64 \%$, pada bulan Mei menurun sebesar $12.16 \%$, pada bulan Juni meningkat sebesar $5.68 \%$, pada bulan Juli menurun sebesar $7.31 \%$, pada bulan Agustus meningkat sebesar $0.74 \%$, pada bulan September menurun sebesar 9.04\%, pada bulan Oktober meningkat sebesar $44.51 \%$, pada bulan November meningkat sebesar $29.88 \%$, pada bulan Desember meningkat sebesar $8.78 \%$. Pada bulan September merupakan jumlah saldo deposito terendah yaitu sebesar Rp. 2.172.500.000. Sedangkan pada bulan Desember merupakan jumlah saldo deposito tertinggi yaitu Rp. 4.435.500.000.
Berdasarkan tabel 2 tahun 2014 dapat dijelaskan jumlah saldo deposito berfluktuasi setiap bulannya. Pada bulan Januari jumlah simpanan deposito sebesar Rp. 2.316.300.000. Pada bulan Februari menurun sebesar $9.94 \%$, pada bulan Maret menurun sebesar $1.63 \%$, pada bulan April meningkat sebesar $16.59 \%$, pada bulan Mei menurun sebesar $8.36 \%$, pada bulan Juni meningkat sebesar $4.31 \%$, pada bulan Juli meningkat sebesar $0.74 \%$, pada bulan Agustus meningkat sebesar $2.26 \%$, pada bulan September meningkat sebesar 3.99\%, pada bulan Oktober meningkat sebesar $3.14 \%$, pada bulan November meningkat sebesar $7.26 \%$, pada bulan Desember meningkat sebesar $8.32 \%$. Pada bulan Mei merupakan jumlah simpanan deposito terendah yaitu sebesar Rp. 2.192.500.000. Sedangkan pada bulan Desember merupakan jumlah simpanan deposito tertinggi yaitu Rp. 2.936.000.000.

Tabel 2 Pertumbuhan Jumlah Simpanan Deposito Periode Tahun 2013-2016.

\begin{tabular}{|c|c|c|c|c|c|c|c|c|}
\hline Bulan & $\begin{array}{c}2013 \\
\text { (Dalam } \\
\text { ribuan) } \\
(\mathrm{Rp}) \\
\end{array}$ & $\%$ & $\begin{array}{c}2014 \\
\text { (Dalam } \\
\text { ribuan) } \\
(\mathrm{Rp}) \\
\end{array}$ & $\%$ & $\begin{array}{c}2015 \\
\text { (Dalam } \\
\text { ribuan) } \\
(\mathrm{Rp}) \\
\end{array}$ & $\%$ & $\begin{array}{c}2016 \\
\text { (Dalam } \\
\text { ribuan) } \\
(\mathrm{Rp}) \\
\end{array}$ & $\%$ \\
\hline Januari & 2.906 .000 & & 2.316 .300 & $-47.78 \%$ & 2.149 .500 & $-26.79 \%$ & 2.132 .200 & $-4.78 \%$ \\
\hline Februari & 2.966 .500 & $2.08 \%$ & 2.086 .000 & $-9.94 \%$ & 2.133 .500 & $-0.74 \%$ & 2.713 .500 & $27.26 \%$ \\
\hline Maret & 2.859 .500 & $-3.61 \%$ & 2.052 .000 & $-1.63 \%$ & 1.952 .500 & $-8.48 \%$ & 1.592 .800 & $-41.30 \%$ \\
\hline April & 2.755 .500 & $-3.64 \%$ & 2.392 .500 & $16.59 \%$ & 2.030 .500 & $3.99 \%$ & 2.931 .000 & $84.02 \%$ \\
\hline Mei & 2.420 .500 & $-12.16 \%$ & 2.192 .500 & $-8.36 \%$ & 2.356 .500 & $16.06 \%$ & 2.107 .300 & $-28.10 \%$ \\
\hline Juni & 2.558 .000 & $5.68 \%$ & 2.287 .000 & $4.31 \%$ & 2.394 .500 & $1.61 \%$ & 2.281 .300 & $8.26 \%$ \\
\hline July & 2.371 .000 & $-7.31 \%$ & 2.304 .000 & $0.74 \%$ & 2.521 .500 & $5.30 \%$ & 2.558 .500 & $12.15 \%$ \\
\hline Agustus & 2.388 .500 & $0.74 \%$ & 2.356 .000 & $2.26 \%$ & 2.491 .500 & $-1.19 \%$ & 2.875 .000 & $12.37 \%$ \\
\hline September & 2.172 .500 & $-9.04 \%$ & 2.450 .000 & $3.99 \%$ & 2.252 .800 & $-9.58 \%$ & 2.095 .000 & $-27.13 \%$ \\
\hline Oktober & 3.139 .500 & $44.51 \%$ & 2.527 .000 & $3.14 \%$ & 2.213 .300 & $-1.75 \%$ & 2.138 .000 & $2.05 \%$ \\
\hline November & 4.077 .500 & $29.88 \%$ & 2.710 .500 & $7.26 \%$ & $\begin{array}{r}2.263 .300 \\
\text { Pand }\end{array}$ & $\begin{array}{l}2.26 \% \\
\text { Made }\end{array}$ & $\begin{array}{l}2.070 .500 \\
\text { yu I Page }\end{array}$ & $\begin{array}{l}-3.16 \% \\
20 \text { dari }\end{array}$ \\
\hline
\end{tabular}


Berdasarkan tabel 2 tahun 2015 dapat dijelaskan jumlah saldo deposito berfluktuasi setiap bulannya. Pada bulan Januari jumlah simpanan deposito sebesar Rp. 2.149.500.000. Pada bulan Februari menurun sebesar $0.74 \%$, pada bulan Maret menurun sebesar $8.48 \%$, pada bulan April meningkat sebesar $3.99 \%$, pada bulan Mei meningkat sebesar $16.06 \%$, pada bulan Juni meningkat sebesar $1.61 \%$, pada bulan Juli meningkat sebesar $5.30 \%$, pada bulan Agustus menurun sebesar $1.19 \%$, pada bulan September menurun sebesar 9.58\%, pada bulan Oktober menurun sebesar $1.75 \%$, pada bulan November meningkat sebesar $2.26 \%$, pada bulan Desember menurun sebesar $1.06 \%$. Pada bulan Maret merupakan jumlah simpanan deposito terendah yaitu sebesar Rp. 1.952.500.000. Sedangkan pada bulan Juli merupakan jumlah simpanan deposito tertinggi yaitu $\mathrm{Rp}$. 2.239.300.000.

\section{SIMPULAN DAN SARAN Simpulan}

Pertumbuhan jumlah simpanan tabungan pada PT. BPR Gisawa Cabang Negara periode tahun 2013-2016 berfluktuasi setiap tahunnya. Pada tahun 2013 pertumbuhan jumlah saldo tabungan di BPR Gisawa sebesar Rp 95.779.694.299. Pada tahun 2014 pertumbuhan jumlah saldo tabungan di BPR Gisawa menurun sebesar 3.56\% menjadi $\mathrm{Rp}$ 92.365.187.109. Pada tahun 2015 pertumbuhan jumlah saldo tabungan di BPR Gisawa menurun sebesar 29.46\% menjadi $\mathrm{Rp}$ 65.156.426.567. Dan pada tahun 2016 pertumbuhan jumlah saldo tabungan di BPR gisawa menurun sebesar 6.01\% menjadi Rp 61.242.604.736. Saldo tabungan yang tertinggi pada PT. BPR Gisawa cabang Negara yaitu tahun 2014 sebesar Rp. 92.365.187.109, dan saldo tabungan yang terendah pada PT. BPR Gisawa Cabang Negara yaitu tahun 2016 sebesar Rp. 61.242.604.736.

Sedangkan Pertumbuhan jumlah simpanan deposito pada PT. BPR Gisawa
Berdasarkan tabel 2 tahun 2016 dapat dijelaskan jumlah saldo deposito berfluktuasi setiap bulannya. Pada bulan Januari jumlah simpanan deposito sebesar Rp. 2.132.200.000. Pada bulan Februari meningkat sebesar $27.26 \%$, pada bulan Maret menurun sebesar $41.30 \%$, pada bulan April meningkat sebesar $84.02 \%$, pada bulan Mei menurun sebesar $28.10 \%$, pada bulan Juni meningkat sebesar $8.26 \%$, pada bulan Juli meningkat sebesar $12.15 \%$, pada bulan Agustus meningkat sebesar $12.37 \%$, pada bulan September menurun sebesar $27.13 \%$, pada bulan Oktober meningkat sebesar $2.05 \%$, pada bulan November menurun sebesar $3.16 \%$, pada bulan Desember meningkat sebesar $6.06 \%$. Pada bulan Maret merupakan jumlah simpanan deposito terendah yaitu sebesar Rp. 1.592.800.000. Sedangkan pada bulan Desember merupakan jumlah simpanan deposito tertinggi yaitu Rp. 2.196.000.000.

Cabang Negara periode tahun 2013-2016 berfluktuasi setiap tahunnya. Pada tahun 2013 pertumbuhan jumlah saldo deposito di BPR gisawa sebesar Rp 35.050.500.000. Pada tahun 2014 pertumbuhan jumlah saldo deposito di BPR Gisawa menurun sebesar $18.38 \%$ menjadi $R p$ 28.609.800.000. Pada tahun 2015 pertumbuhan jumlah saldo deposito di BPR Gisawa menurun sebesar $5.63 \%$ menjadi Rp 26.998.700.000. Dan pada tahun 2016 pertumbuhan jumlah saldo deposito di BPR gisawa meningkat sebesar $2.56 \%$ menjadi Rp 27.691.100.000. Saldo deposito yang tertinggi pada PT. BPR Gisawa cabang Negara yaitu tahun 2013 sebesar Rp. 35.050.500.000, dan saldo deposito akhir tahun yang terendah pada PT. BPR Gisawa Cabang Negara yaitu tahun 2016 sebesar Rp. 27.691.100.000.

Penyebab terjadinya fluktuasi tingkat pertumbuhan simpanan tabungan dan deposito pada PT. BPR Gisawa Cabang Negara periode tahun 2013-2016, yaitu tingkat persaingan antar Bank Perkreditan Rakyat yang tinggi yang dapat mengakibatkan bergesernya kepercayaan

Pande Made Ayu I Page 21 dari 51 
nasabah untuk melakukan transaksi tabungan di PT. BPR Gisawa Cabang Negara, dan tingkat kepercayaan nasabah yang masih cenderung rendah terhadap PT. BPR Gisawa

\section{Saran}

Berdasarkan simpulan di atas, maka dapat dikemukakan beberapa saran calon nasabah, melakukan promosi dan pemberian hadiah yang menarik bagi nasabah sebagai upaya agar masyarakat tertarik melakukan transaksi, melakukan pengembangan dalam bidang teknologi perbankan untuk memenuhi kebutuhan masyarakat yang semakin luas, meningkatkan pelayanan dan kenyamanan kepada nasabah baik dari segi pegawai melayani nasabah sampai kepada kenyamanan ruangan, menawarkan suku bunga yang bersaing, serta menawarkan berbagai macam kemudahan bagi calon nasabah.

Bagi Akademik, Bagi peneliti lain yang hendak meneliti pada Bank Perkreditan Rakyat, diharapkan mampu mengembangkan suatu permasalahan baru dengan melakukan analisis pada kredit di Bank Perkreditan Rakyat, untuk mengetahui apakah analisis simpanan dan analisis kredit berjalan stabil sesuai yang diharapkan. Sehingga bisa digunakan untuk acuan dalam mencapai kinerja yang lebih baik.

\section{DAFTAR PUTAKA}

Anonim, Berbagai Edisi. Statistik Ekonomi Keuangan Indonesia. Jakarta : Bank Indonesia.

Hasibuan, Malayu. 2005. Manajemen Sumber Daya Manusia. Jakarta : Bumi Aksara.

Ikatan Akuntansi Indonesia. 2002. Standar Akuntansi Keuangan. Jakarta : Salemba Empat.

Ismail. 2010. Manajemen Perbankan. Jakarta: Kencana Prenada Media Group.

Kasmir. 2002. Bank dan Lembaga Keuangan Lainnya. Edisi Revisi sebagai berikut. Bagi PT. BPR Gisawa Cabang Negara, PT. BPR Gisawa sebaiknya menggunakan strategi untuk menarik minat masyarakat melakukan transaksi di PT. BPR Gisawa agar pertumbuhan simpanan tetap berjalan stabil seperti, melakukan pendekatan terhadap

2002. Jakarta : Rajagrafindo Persada.

-------. 2003. Manajemen Perbankan. Jakarta : Rajagrafindo Persada.

------. 2005. Dasar-Dasar Perbankan. Jakarta: PT. Rajagrafindo Persada.

-------. 2012. Analisis Laporan Keuangan. Jakarta: PT. Grafindo Persada.

2015. Bank dan Lembaga Keuangan Lainnya. Jakarta: Prehallindo.

Kotler. 2002. Manajemen Pemasaran, Jilid 1, Edisi Milenium. Jakarta: Prehallindo.

Kotler. 2005. Manajemen Pemasaran, Jilid 2, Edisi Milenium. Jakarta: Pearson Education Asia PT.e. Ltd dan PT. Prehallindo.

Nazir, Habib, dan Muhamad Hassanudin. 2004. Ensiklopedi Ekonomi dan Perbankan Syariah. Bndung : Kaki Langit

Parera, JD. 2004. Bank Indonesia, Bank Sentral, Republik Indonesia, Suatu Pengantar Penerbit Pusat Pendidikan dan Study Kebanksentralan (PPSK). Jakarta: Bank Indonesia.

Simurangkir. 2002. Pengantar Lembaga Keuangan Bank dan Non Bank. Bogor : Ghalia Indonesia.

Simurangkir. 2004. Pengantar Lembaga Keuangan Bank dan Non Bank. Jakarta : Rajagrafindo.

Sinungan, Muchdarsyah. Drs. (2000). Manajemen Dana Bank. Jakarta. PT Budi Aksara.

Pande Made Ayu I Page 22 dari 51 
Susilo, dkk. 2000. Bank dan Lembaga Keuangan Lainnya. Edisi Satu. Jakarta : Salemba Empat.

Susilo. 2004. Manajemen Perbankan. Jakarta: Raja Grafindo Persada.
Suyatno. 2004. Kelembagaan Perbankan. Jakarta: PT. Gramedia.

Veithzal, Rivai. 2007. Bank dan Financial Institude Management. Jakarta: PT. Grafindo Persada. 